Doi: 10.30868/ad.v3i01.752

\title{
ANALYSIS OF VALUE FOR MONEY INCOME BUDGETS GOVERNMENT OF THE CITY OF MEDAN
}

\section{ANALISIS VALUE FOR MONEY ANGGARAN PENDAPATAN PADA PEMERINTAH KOTA MEDAN}

\author{
Hendra Harmain, Aqwa Naser Daulay, Debby Tamara Enre \\ ${ }^{1,2,3}$ UIN Medan Sumatra Utara Medan \\ hendra.rafa@gmail.com \\ aqwanaserdaulay@uinsu.ac.id \\ debby.tamaraa@gmail.com
}

\begin{abstract}
Problems that often arise in the implementation of the Revenue Budget and Regional Expenditure is a waste of budget use done and not on target which should be felt by the community general. This study aims to determine the financial performance of the City Government The terrain is measured using the Value for Money method which consists of economical, efficiency, and effectiveness, and to find out whether financial performance calculated using the Value for Money method in accordance with the Ministry of Home Affairs No. 600,900-327 of 1996. This research was conducted at the Financial Management Agency and Regional Assets of Medan City. This research approach is in the form of an approach descriptive research that is conducted by collecting and presenting data received from the Medan City Government in the form of data on the amount of the Budget Regional Government Revenue and Expenditures Medan City Government thus provides the writerss to analyze and compare with existing theory. The data analysis technique used is descriptive analysis technique qualitative. The results showed that, the performance of Local Government Medan City regency during 2014-2018 has not been economical because it has an average economic ratio of $79 \%$ and included in the category of less economical. In terms of efficiency it is less efficient because it has an average efficiency ratio $99.71 \%$. And in terms of effectiveness, the average effectiveness ratio is $82.49 \%$ which is in the quite effective category. The economic ratio of the Medan City Government has decreased, the ratio of regional spending efficiency has increased, the ratio the effectiveness of regional income has decreased, and the performance of the City Government The terrain measured using Value for Money has decreased. This happens due to the lack of maximum regional income, as evidenced by regional income that is not able to reach the target, and increased spending Regional Government of Medan City. Then it can be said that the Value for Money Ratio the Medan City Government has not met the standards based on the Minister of Home Affairs. No. 600,900-327 of 1996. Factors causing Value for Money have not been fulfilled standard because of the amount of realization of regional expenditure incurred, and also local governments are not able to achieve the revenue targets that have been determined by the Regional Government.
\end{abstract}

Keywords: value for money, revenue budget, government, analyze 


\section{A. PENDAhuluan}

Kemampuan pemerintah daerah khususnya Pemerintah Kota Medan dalam mengelola keuangan termuat dalam Anggaran Pendapatan dan Belanja Daerah (APBD) yang menggambarkan kemampuan pemerintah daerah dalam membiayai pelaksanaan tugas pembangunan. Dalam menjalankan otonomi daerah, pemerintah dituntut untuk menjalankan roda pemerintahan yang efektif dan efisien mampu mendorong peran serta masyarakat dalam pembangunan, serta meningkatkan pemerataan dan keadilan dengan mengembangkan seluruh potensi yang dimilikimasing-masing daerah.

Tuntutan yang tinggi pada kebutuhan pengukuran kinerja pemerintah mempunyai banyak tujuan. Tujuan tersebut paling tidak untuk meningkatkan kinerja dan meningkatkan akuntabilitas pemerintah daerah. Untuk itu, pemerintah daerah dituntut untuk mampu membangun ukuran kinerja yang baik. Ukuran kinerja yang disusun tidak dapat hanya dengan menggunakan satu ukuran. Oleh karena itu perlu ukuran yang berbeda untuk tujuan yang berbeda (Mahsun, 2006: 299).

Keberhasilan otonomi daerah tidak lepas dari kinerja pemerintah dalam mengelola keuangan daerahnya. Ukuran kinerja pemerintah berdasarkan anggaran berbasis kinerja dapat diukur dengan menggunakan konsep Value for Money (Indra Bastian, 2006: 335). Tuntutan akan kualitas dan profesionalisme sektor publik dapat dinilai dengan menggunakan konsep Value for Money (Nilai daripada Uang) dalam menjalankan aktivitasnya. Value for Money merupakan konsep pengelolaan organisasi sektor publik yang mendasarkan pada tiga elemen utama, yaitu: ekonomi, efisiensi,

dan efektivitas (Mardiasmo, 2002: 27). Dengan demikian, suatu daerah yang kinerja keuangannya dinyatakan baik berarti daerah tersebut memiliki kemampuan keuangan untuk membiayai pelaksanaan otonomi daerah (Nordiawan, 2009: 164). Kemudian Untuk dapat mengukur tingkat ekonomi, efisiensi, dan efektivitas, organisasi pemerintahan harus dapat mengetahui tingkat input, output, dan outcome.

Kota Medan memiliki banyak potensi yang dapat digali untuk dapat dijadikan sumber pendapatan dari berbagai sektor. Perekonomian Kota Medan digerakkan oleh sektor perdagangan/ hotel/ restoran, telekomunikasi dan transportasi, dan industri pengelolaan yang dapat meningkatkan PAD. Dan salah satu pendapatan terbesar Kota Medan adalah pajak daerah dan retribusi daerah. Jika kinerja keuangan Pemerintah Daerah sudah memenuhi kriteria ekonomi, efisiensi, dana 
efektif maka dapat meningkatkan pendapatan asli daerah.

Tetapi permasalahan yang sering timbul dalam pelaksanaan APBD adalah adanya pemborosan penggunaan anggaran belanja yang dibelanjakan dan tentu saja tidak tepat sasaran yang seharusnya dapat dirasakan oleh masyarakat umum. Sebagai contoh, proyek pembangunan tanpa manfaat yang dilakukan pemerintah kota Medan yaitu Proyek Sky Bridge yang menghubungkan Lapangan Merdeka dengan Stasiun KAI-Medan, yang selesai dibangun Desember 2014 lalu. Sampai saat ini proyek anggaran sebesar Rp 35 Miliar tersebut tidak memberi manfaat apapun bagi warga kota karena tak kunjung difungsikan dan terbengkalai (Gatra, 2019). Pemerintah Kota Medan seharusnya lebih memprioritaskan permasalahan perbaikan jalan terutama ruas jalan protokol di Kota Medan karena masih banyak yang mengalami kerusakan, lampu penerangan jalan umum yang tidak terawat, permasalahan banjir yang masih terjadi di beberapa kawasan dan masih banyak drainase yang rusak.

Berikut ini adalah laporan realisasi anggaran pemerintah kota medan dari tahun 2014-2018:

\section{Tabel 1}

Laporan Realisasi Anggaran Pemerintah Kota Medan

Tahun 2014-2018

(dalam rupiah)

\begin{tabular}{|c|c|c|c|}
\hline Tahun & Uraian & Anggaran & Realisasi \\
\hline \multirow[t]{2}{*}{$\begin{array}{l}201 \\
4\end{array}$} & $\begin{array}{l}\text { Pendapata } \\
\text { n Daerah }\end{array}$ & $\begin{array}{l}4.560 .412 .529 .543 \\
, 87\end{array}$ & $\begin{array}{l}4.042 .115 .828 .231 \\
, 62\end{array}$ \\
\hline & Belanja & 4.625 .169 .942 .881 & $\begin{array}{l}3.723 .643 .299 .085 \\
, 60\end{array}$ \\
\hline \multirow[t]{2}{*}{$\begin{array}{l}201 \\
5\end{array}$} & $\begin{array}{l}\text { Pendapata } \\
\text { n Daerah }\end{array}$ & $\begin{array}{l}5.046 .111 .839 .162 \\
, 45\end{array}$ & $\begin{array}{l}4.259 .044 .490 .715 \\
, 42\end{array}$ \\
\hline & Belanja & 5.467 .952 .757 .114 & $\begin{array}{l}4.374 .968 .274 .136 \\
, 94\end{array}$ \\
\hline \multirow[t]{2}{*}{$\begin{array}{l}201 \\
6\end{array}$} & $\begin{array}{l}\text { Pendapata } \\
\text { n Daerah }\end{array}$ & $\begin{array}{l}5.490 .162 .683 .364 \\
, 97\end{array}$ & $\begin{array}{l}4.308 .116 .916 .024 \\
, 91\end{array}$ \\
\hline & Belanja & 5.735.922.591.995 & $\begin{array}{l}4.523 .672 .134 .655 \\
, 15\end{array}$ \\
\hline \multirow[t]{2}{*}{$\begin{array}{l}201 \\
7\end{array}$} & $\begin{array}{l}\text { Pendapata } \\
\text { n Daerah }\end{array}$ & 5.523 .623 .117 .419 & 4.409 .065 .482 .201 \\
\hline & Belanja & $\begin{array}{l}5.554 .084 .308 .979 \\
40\end{array}$ & 4.395 .825 .169 .225 \\
\hline \multirow[t]{2}{*}{$\begin{array}{l}201 \\
8\end{array}$} & $\begin{array}{l}\text { Pendapata } \\
\text { n Daerah }\end{array}$ & 5.238 .966 .379 .116 & 4.253 .618 .758 .533 \\
\hline & Belanja & 5.451 .085 .765 .928 & 4.215 .003 .353 .126 \\
\hline
\end{tabular}

\section{Sumber: Badan Pengelola Keuangan dan Aset Daerah}

Pada tabel laporan realisasi anggaran diatas menjelaskan bahwa laporan realisasi anggaran pemerintah Kota Medan meliputi pendapatan, belanja, dan pembiayaan. Pendapatan Daerah Pemerintah Kota Medan dan Belanja Daerah Pemerintah Kota Medan jika dilihat dari tahun 20142017 mengalami peningkatan setiap tahunnya. Namun pada tahun 2018, Anggaran realisasi pada belanja dan pendapatan daerah mengalami penurunan, akibat tidak ada nya anggaran P-APBD kota medan di tahun 2018.

Berdasarkan uraian diatas, maka penulis tertarik untuk melakukan penelitian dan menganalisis masalah yang akan menjadi focus penelitian, yaitu "Bagaimana 
kinerja keuangan Pemerintah Kota Medan berdasarkan Rasio Value for Money?"

\section{B. LANDASAN TEORITIS}

\section{Keuangan Daerah}

Keuangan Daerah adalah semua hak dan kewajiban daerah dalam rangka kegiatan penyelenggaraan pemerintahan daerah yang dapat dinilai dengan uang termasuk juga di dalamnya segala bentuk kekayaan ataupun harta yang berhubungan dengan hak dan kewajiban atas daerah tersebut, yang terdapat dalam kerangka Anggaran Pendapatan dan Belanja Daerah (Halim, 2007:19).

Guna mewujudkan keuangan daerah yang transparan dan akuntabel, dibutuhkan pengelolaan dengan suatu sistem manajemen keuangan yang jelas dan berdaya guna. Manajemen merupakan proses perencanaan, pengorganisasian, pengarahan, pengkoordinasian, dan pengawasan usaha-usaha para anggota organisasi dan penggunaan sumber daya organisasi lainnya agar mencapai tujuan yang telah ditetapkan. Dari pengertian tersebut, jelas bahwa manjemen mempunyai empat fungsi dasar, yaitu perencanaan, pengorganisasian, kepemimpinan, dan pengendalian.

Konsep dasar dari manajemen tersebut dapat diaplikasikan dalam berbagai jenisorganisasi, termasuk lingkungan organisasi sektor publik tidak terkecuali dalam pengelolaan keuangan daerah. Beberapa prinsip penting manajemen keuangan daerah yaitu:

a. Taat pada peraturan perundangundangan, dengan maksud bahwa pengelolaan keuangan daerah harus berpedoman pada peraturan perundang-undangan.

b. Efektif merupakan pencapaian hasil program dengan target yang telah ditetapkan, yaitu dengan cara membandingkan keluaran dengan hasil.

c. Efisien merupakan pencapaian keluaran yang maksimum dengan masukan tertentu atau penggunaan masukan terendah untuk mencapai keluaran tertentu.

d. Ekonomis merupakan perolehan masukan dengan kualitas dan kuantitas tertentu pada tingkat harga terendah.

e. Transparan merupakan prinsip keterbukaan yang memungkinkan masyarakat untuk mengetahui dan mendapatkan akses informasi seluasluasnya tentang keuangan daerah.

f. Bertanggungjawab merupakan wujud dari kewajiban seseorang untuk mempertanggungjawabkan pengelolaan dan pengendalian 


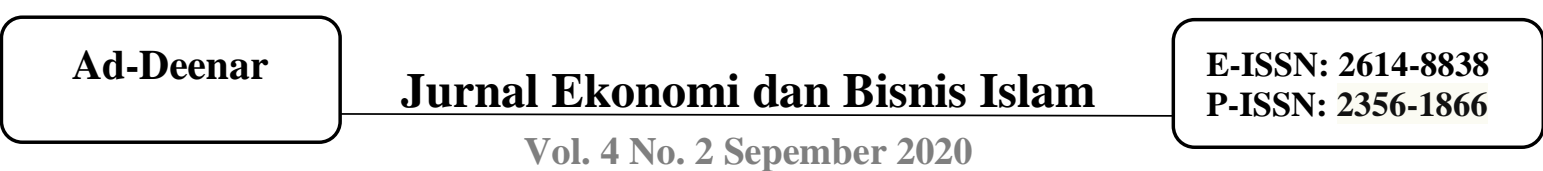

Vol. 4 No. 2 Sepember 2020

sumber daya dan pelaksanaan kebijakan yang dipercayakan kepadanya dalam rangka pencapaian tujuan yang telah ditetapkan.

g. Keadilan adalah keseimbangan distribusi kewenangan dan pendanaannya dan/atau keseimbangan distribusi hak dan kewajiban berdasarkan pertimbangan yang objektif.

h. Kepatutan adalah tindakan atau suatu sikap yang dilakukan dengan wajar dan proposional.

i. Manfaat maksudnya keuangan daerah diutamakan untuk pemenuhan kebutuhan masyarakat.

Secara garis besar, manajemen keuangan daerah dapat dibagi menjadi dua bagian, yaitu manajemen penerimaan daerah dan manajemen pengeluaran daerah. Evaluasi terhadap pengelolaan keuangan daerah dan pembiayaan pembangunan daerah mempunyai implikasi yang sangat luas. Kedua komponen tersebut akan sangat menentukan kedudukan suatu pemerintah daerah dalam rangka pelaksanaan otonomi daerah (Halim, 2002: 27).

\section{Anggaran Pendapatan Daerah}

Pendapatan daerah merupakan penerimaan yang sangat penting bagi pemerintah daerah dalam menunjang pembangunan daerah guna membiayai proyek-proyek dan kegiatan-kegiatan daerah. Kemudian berdasarkan Peraturan Pemerintah Republik Indonesia Nomor 105 Tahun 2000 tentang Pengelolaan dan Pertanggungjawaban Keuangan Daerah yang dimaksud dengan Pendapatan Daerah adalah semua penerimaan kas daerah dalam periode tahun anggaran tertentu menjadi hak daerah. Berdasarkan kedua pengertian tersebut dapat diambil kesimpulan bahwa pendapatan daerah merupakan penerimaan yang diperoleh pemerintah daerah yang dapat ditinjau dari tingkat kenaikan aktiva ataupun penurunan utang yang dapat digunakan oleh pemerintah dalam membangun dan mengembangkan suatu daerah dalam periode tahun anggaran yang bersangkutan.

\section{Anggaran Belanja Daerah}

Menurut Indra Bastian dan Gatot Soepriyono yang mengemukakan bahwa belanja daerah adalah penurunan manfaat ekonomis masa depan atau jasa potensial selama periode pelaporan dalam bentuk arus kas keluar, atau konsumsi aktiva/ekuitas netto, selain yang berhubungan dengan distribusi ke entitas ekonomi itu sendiri (Supriyanto, 2003: 57). Dari pengertian tersebut, maka dapat disimpulkan bahwa belanja daerah adalah semua kewajiban daerah yang diakui sebagai pengurang nilai kekayaan bersih dalam periode tahun anggaran yang 
bersangkutan. Belanja daerah dipergunakan dalam rangka mendanai pelaksanaan urusan pemerintahan yang menjadi kewenangan provinsi/kabupaten/kota yang terdiri atas urusan wajib, urusan pilihan, dan urusan yang penanganannya dalam bagian atau bidang tertentu yang dapat dilaksanakan bersama pemerintah pusat dan pemerintah daerah atau antar pemerintah daerah yang ditetapkan dengan ketentuan perundangundangan.

\section{Anggaran Pendapatan dan Belanja}

\section{Daerah}

Anggaran Pendapatan dan Belanja Daerah merupakan cermin dari pilihanpilihan ekonomis dan sosial masyarakat suatu daerah untuk menjalankan peran yang dimandatkan masyarakat untuk menjadikan pilihan-pilihan tersebut. Pemerintah daerah harus melaksanakan fungsi pertama, pengumpulan sumber daya yang mencukupi dengan cara yang tepat, dan kedua, pengalokasian dan penggunaan sumber daya tersebut secara responsif, efisien dan efektif. Fungsi pertama berkaitan dengan sisi penerimaan (pendapatan) dari APBD sedangkan fungsi kedua dari sisi pengeluaran (belanja).

\section{Kinerja Keuangan Daerah}

Kinerja merupakan pencapaian atas apa yang direncanakan, baik oleh pribadi maupun organisasi. Apabila pencapaian sesuai dengan yang direncanakan, maka kinerja yang dilakukan terlaksana dengan baik. Apabila pencapaian melebihi dari apa yang direncanakan dapat dikatakan kinerjanya sangat bagus. Apabila pencapaian tidak sesuai dengan apa yang direncanakan atau kurang dari apa yang direncanakan, maka kinerjanya jelek. Kinerja keuangan adalah suatu ukuran kinerja yang menggunakan indikator keuangan. Analisis kinerja keuangan pada dasarnya dilakukan untuk menilai kinerja di masa lalu dengan melakukan berbagai analisis sehingga diperoleh posisi keuangan yang mewakili realitas entitas dan potensipotensi kinerja yang akan berlanjut. Salah satu alat untuk menganalisis kinerja keuangan pemerintah daerah adalah dengan melaksanakan analisis rasio terhadap APBD yang telah ditetapkan dan dilaksanakannya (Halim, 2002: 230).

Inti dari pengukuran kinerja dari organisasi pemerintahan adalah implementasi konsep Value for Money. Value for Money memiliki tiga komponen yaitu: ekonomi, efisiensi dan efektif. Untuk bisa mengukur tingkat ekonomi, efisiensi, dan efektivitas, organisasi pemerintahan harus dapat mengetahui tingkat input, output, dan outcome.

\section{Value for Money}

Value for money merupakan inti pengukuran kinerja pada organisasi pemerintah. Kinerja pemerintah tidak dapat 
dinilai dari output yang dihasilkan saja, akan tetapi harus mempertimbangkan input, output, dan outcome secara bersama-sama. Value for money merupakan konsep pengelolaan organisasi sektor publik yang mendasarkan pada tiga elemen utama yaitu ekonomi, efisiensi, dan efektivitas (Mardiasmo, 2002: 4).

Menurut Mardiasmo Indikator Value for Money dibagi menjadi dua bagian seperti yang dijelaskan antara lain:

a. Indikator alokasi biaya (ekonomi dan efisiensi)

b. Indikator kualitas pelayanan (efektivitas)

Indikator kinerja dapat dimanfaatkan oleh pihak internal maupun eksternal. Pihak internal dapat menggunakannya dalam rangka meningkatkan kualitas dan kuantitas pelayanan serta efisiensi biaya. Dengan kata lain, indikator kinerja berperan untuk menunjukkan, memberikan indikasi atau memfokuskan perhatian pada bidang yang relevan dilakukan tindakan perbaikan.

Pihak eksternal dapat menggunakan indikator kinerja sebagai kontrol dan sekaligus sebagai informasi dalam rangka mengukur tingkat akuntabilitas publik. Pembuatan dan penggunaan indikator kinerja tersebut membantu setiap pelaku utama dalam proses pengeluaran publik. Indikator kinerja akan membantu para manajer publik untuk memonitor pencapaian program dan mengidentifikasi masalah yang penting.

Langkah-langkah Pengukuran Value for Money:

1) Pengukuran Ekonomi

Pengukuran ekonomi hanya mempertimbangkan masukan yang digunakan, ekonomi merupakan ukuran relatif. Ekonomi merupakan perbandingan antara input dan input value. Input dalam hal ini adalah target anggaran, sedangkan input value adalah realisasi anggaran. Jadi dapat disimpulkan bahwa suatu kinerja dikatakan ekonomis apabila realisasi anggaran lebih kecil dari pada target anggaran dan dapat mencapai output sesuai dengan yang telah ditetapkan.

Dari penjelasan tersebut, secara matematis pengukuran ekonomi dapat dilakukan dengan perhitungan sebagai berikut:

\section{Ekonomi}

Realisasi Biaya Untuk Memperoleh Pendapatan Anggaran Biaya Untuk Memperoleh Pendapatan $\mathrm{x} 100 \%$

Untuk mengetahui seberapa besar tingkat rasio ekonomis dari hasil perhitungan yang dilakukan, maka dapat 
menggunakan formula rasio ekonomis adalah klasifikasi atas pengukuran rasio ekonomi.

Tabel 2

Klasifikasi Pengukuran Ekonomis

\begin{tabular}{|l|l|}
\hline Persentase & Kriteria \\
\hline $100 \%$ Keatas & Sangat Ekonomis \\
\hline $90 \%-100 \%$ & Ekonomis \\
\hline $80 \%-90 \%$ & Cukup Ekonomis \\
\hline $60 \%-80 \%$ & Kurang Ekonomis \\
\hline $\begin{array}{l}\text { Kurang dari } \\
60 \%\end{array}$ & Tidak Ekonomis \\
\hline
\end{tabular}

Sumber: Kepmendagri

No.600.900-327

2) Pengukuran Efisiensi

Pengukuran efisiensi dilakukan dengan menggunakan perbandingan antara output yang dihasilkan terhadap input yang digunakan. Proses kegiatan operasional dapat dikatakan efisien apabila suatu produk atau hasil kerja tertentu dapat dicapai dengan penggunaan sumber daya dan dana yang serendahrendahnya.

Pengukuran tingkat efisiensi memerlukan data-data realisasi biaya untuk memperoleh pendapatan dan data realisasi pendapatan $^{1}$. Rumus perhitungannya sebagai berikut:

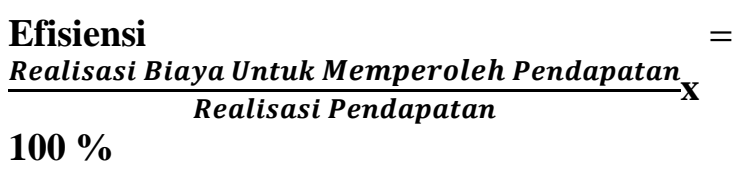

Pengukuran efisiensi tidak dinyatakan dalam bentuk absolut tetapi dalam bentuk relatif karena efisiensi diukur dengan membandingkan keluaran dan masukan. Perbaikan efesiensi dapat dilakukan dengan:

a) Meningkatkan output pada tingkat input yang sama

b) Meningkatkan output dalam proporsi yang lebih besar daripada proporsi peningkatan input

c) Menurunkan input pada tingkatan output yang sama

d) Menurunkan input dalam proporsi yang lebih bes

e) Menurunkan input dalam proporsi yang lebih besar daripada proporsi penurunan output.

Untuk mengetahui seberapa besar tingkat rasio efisiensi dari hasil perhitungan yang dilakukan, maka dapat menggunakan formula rasio efisiensi adalah klasifikasi atas pengukuran rasio efisiensi. 
Tabel 3

Klasifikasi Pengukuran Efisiensi
\begin{tabular}{|l|l|}
\hline Persentase & Kriteria \\
\hline $100 \%$ Keatas & Tidak Efisien \\
\hline $90 \%-100 \%$ & Kurang Efisien \\
\hline $80 \%-90 \%$ & Cukup Efisien \\
\hline $60 \%-80 \%$ & Efisien \\
\hline $\begin{array}{l}\text { Kurang dari } \\
60 \%\end{array}$ & Sangat Efisien \\
\hline
\end{tabular}

Sumber: Kepmendagri

No.600.900-327

3) Pengukuran Efektivitas

Efektivitas adalah ukuran berhasil tidaknya suatu organisasi mencapai tujuannya. Efektivitas tidak menyatakan tentang berapa besar biaya yang telah dikeluarkan untuk mencapai tujuan tersebut.Suatu organisasi sektor publik dapat dikatakan efektif apabila organisasi tersebut dapat mencapai tujuan yang telah ditetapkan. $^{2}$ Jadi secara sistematis, efektivitas dapat dihitung dengan rumus sebagai berikut:

\section{Efektivitas \\ Realisasi Pendapatan $\frac{\text { Target Pendapatan }}{\text { Pata }} 100 \%$}

Untuk mengetahui tingkat efektivitas dari hasil perhitungan menggunakan formula efektivitas adalah klasifikasi pengukuran efektivitas.

\section{Tabel 4}

\section{Klasifikasi Pengukuran Efektivitas}

\begin{tabular}{|l|l|}
\hline Persentase & Kriteria \\
\hline $100 \%$ Keatas & Sangat Efektif \\
\hline $90 \%-100 \%$ & Efektif \\
\hline $80 \%-90 \%$ & Cukup Efektif \\
\hline $60 \%-80 \%$ & Kurang Efektif \\
\hline Kurang dari 60\% & Tidak Efektif \\
\hline \multicolumn{2}{|l|}{ Sumber: Kepmendagri No.600.900-327 }
\end{tabular}

\section{Kerangka Berpikir}

Value for Money merupakan inti pengukuran kinerja pada organisasi pemerintah. Kinerja pemerintah tidak dapat dinilai dari output yang dihasilkan saja, akan tetapi harus mempertimbangkan input, output, dan outcome secara bersama-sama. Bahkan untuk beberapa hal perlu ditambahkan pengukuran distribusi dan cakupan layanan (equity and service coverage).Tujuan value for money adalah untuk meningkatkan akuntabilitas lembaga sektor publik dan memperbaiki kinerja pemerintah. Adapun alur penelitian dalam penelitian ini yaitu:

${ }^{2}$ Mardiasmo, Akuntansi Sektor Publik, 2009, h. 134 . 


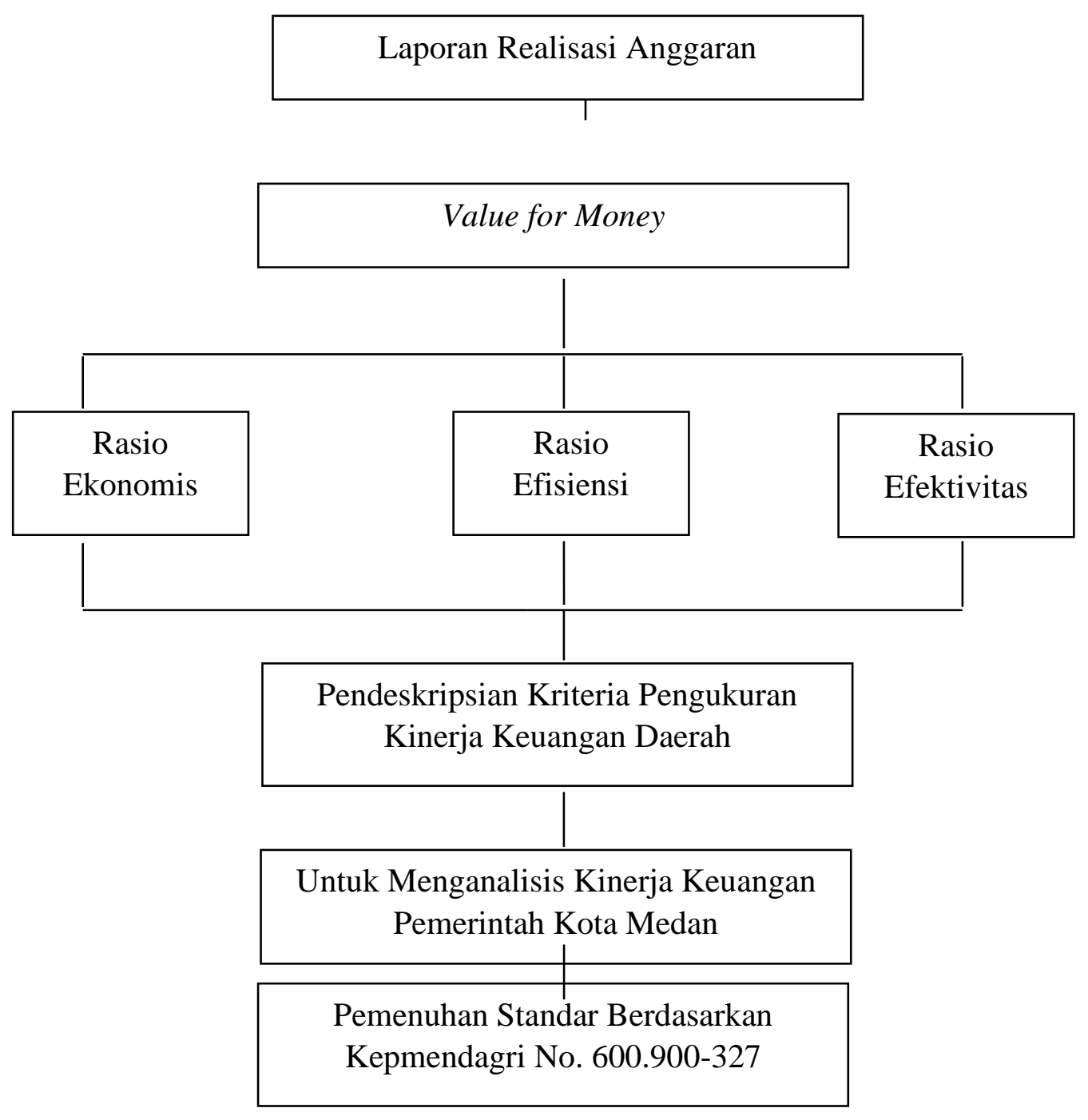

2.1 Kerangka Berpikir

Gambar 1 Alur Penelitian 


\section{METODOLOGI PENELITIAN}

\section{Pendekatan Penelitian}

Penelitian ini menggunakan pendekatan penelitian deskriptif kualitatif, penelitian yang merupakan data yang diperoleh disusun sedemikian rupa kemudian dianalisis berdasarkan teori-teori yang relevan dengan permasalahan untuk mengambil kesimpulan dan saran (Umar, 2004:142). Penelitian ini bertujuan untuk mendeskripsikan kondisi dari kinerja keuangan Kota Medan jika dilihat atau dinilai menggunakan Rasio Value for Money dengan dengan mengumpulkan dan menyajikan data yang diterima dari Pemerintah Kota Medan berupa data-data jumlah anggaran pendapatan dan belanja daerah, realisasi pendapatan dan belanja daerah kota medan sehingga memberikan gambaran yang cukup jelas untuk penulis menganalisis serta membandingkan dengan teori yang ada.

\section{Tempat dan Waktu Penelitian}

Penelitian dilakukan pada Kantor Pemerintahan Kota Medan Badan Pengelola Keuangan dan Aset Daerah yang beralamat di Jalan Kapten Maulana Lubis No. 2 Medan 20112 Provinsi Sumatera Utara. Adapun waktu penelitian ini dimulai pada bulan 06 Maret 2020 sampai dengan 06 April 2020.

\section{Subjek dan Objek}

Subjek dalam penelitian ini adalah Kepala Bidang Anggaran (Syahrial Rangkuti), Anggota/Staf bidang anggaran (Nina Anggina Lubis), Anggota/Staf sub bidang pendapatan (Erlina Riz).

\section{Tabel 5}

Data Subjek Penelitian

\begin{tabular}{|c|l|l|l|}
\hline $\begin{array}{l}\text { N } \\
\text { o. }\end{array}$ & Nama & Jabatan & Bidang \\
\hline 1 & $\begin{array}{l}\text { Syahri } \\
\text { al } \\
\text { Rangk } \\
\text { uti }\end{array}$ & $\begin{array}{l}\text { Kepala } \\
\text { Bidang }\end{array}$ & Anggaran \\
\hline 2 & $\begin{array}{l}\text { Nina } \\
\text { Anggi } \\
\text { na } \\
\text { Lubis }\end{array}$ & $\begin{array}{l}\text { Anggota/ } \\
\text { Staf }\end{array}$ & Anggaran \\
\hline 3 & $\begin{array}{l}\text { Erlina } \\
\text { Riz }\end{array}$ & $\begin{array}{l}\text { Anggota/ } \\
\text { Staf }\end{array}$ & $\begin{array}{l}\text { Sub bidang } \\
\text { pendapatan }\end{array}$ \\
\hline
\end{tabular}

Adapub Objek penelitian merupakan sesuatu yang mejadi perhatian dalam sebuah penelitian karena objek penelitian merupakan sasaran yang hendak dicapai untuk mendapatkan jawaban maupun solusi dari permasalahan yang terjadi. Objek pada penelitian ini adalah Laporan Realisasi APBD Kota Medan tahun 2014-2018.

\section{Jenis dan Sumber Data}

Data primer adalah sumber data penelitian yang didapat secara langsung dari sumber asli dan tidak melalui perantara. Data primer dalam penelitian ini berupa data kualitatif , berupa gambaran umum dari Pemerintah Kota medan dan gambaran umum Badan Pengelolaan Keuangan dan Aset Daerah (BPKAD) Kota 
Medan yang bersumber dari website pemkomedan.go.id dan data yang diambil langsung dari objek penelitian yaitu hasil dari wawancara dengan pihak-pihak yang terkait di Kantor Walikota Medan.

Data sekunder merupakan data primer sesudah diolah dan data yang bersumber dari laporan yang telah dibuat oleh pihak lain. Data sekunder dalam penelitian ini berupa data kuantitif berupa Laporan Realisasi Anggaran Pemerintah kota Medan tahun 2014-2018.

\section{Teknik Pengumpulan Data}

Teknik yang digunakan untuk memperoleh data dalam penelitian ini adalah pengamatan langsung, wawancara, dan studi dokumentasi.

\section{Teknik Analisis Data}

Pada tahap awal penelitian ini dilakukan pengumpulan data sampel melalui sumber data berupa dokumen laporan keuangan, kemudian data tersebut diolah dan dihitung dengan menggunakan rasio guna mendapatkan gambaran mengenai kondisi kinerja keuangan. Hasil perhitungan rasio yang sudah diperoleh kemudian disusun dalam bentuk analisis deskriptif guna menjelaskan makna dari angka-angka yang diperoleh dari hasil perhitungan tersebut.

Dalam hal ini, data yang diperoleh dianalisis menggunakan metode rasio Value for Money dengan membandingkan hasil dari perhitungan rasio terhadap Laporan keuangan Pemerintah kota Medan dari 2014-2018.

Adapun tolak ukur yang dapat digunakan dalam teknik analisis menggunakan rasio ekonomi, efesiensi, efektivitas adalah:

\section{Ekonomi $=$}

Realisasi Biaya Untuk Memperoleh Pendapatan $\overline{\text { Anggaran Biaya Untuk Memperoleh Pendapatan }}$ $\mathrm{x} 100 \%$

Efisiensi $=$
$\frac{\text { Realisasi Biaya Untuk Memperoleh Pendapatan }}{\text { Realisasi Pendapatan }}$
x $100 \%$

Efektivitas $=\frac{\text { Realisasi Pendapatan }}{\text { Target Pendapatan }} \times 100 \%$

Hal tersebut akan dianalisis berdasarkan langkah-langkah yang dibuat penulis dalam teknik analisis data ini adalah:

a. Collecting/Pengumpulan data, berkaitan dengan laporan realisasi anggaran Kota Medan yang diperoleh dari hasil observasi.

b. Reduksi data, yaitu memilih hal-hal pokok yang sesuai dengan fokus penelitian. Dalam penelitian ini peneliti memfokuskan pada laporan realisasi anggaran instansi. Terlebih dahulu peneliti mengklarifikasi data realisasi dan anggaran yang telah diperoleh, kemudian mengolah serta menghubungkan semua data yang 
telah diperoleh dengan teori yang ada. Pengukuran kinerja keuangan ditinjau menggunakan metode value for money dengan menghitung rasio ekonomi, rasio efisiensi, dan rasio efektivitas anggaran pendapatan dengan menggunakan data yang diperoleh.

c. Penyajian data, sekumpulan informasi yang telah tersusun yang memberikan kemungkinan adanya penarikan kesimpulan dan pengambilan tindakan. Penyajian data berupa analisis dalam bentuk uraian singkat, sehingga peneliti dapat menguasai data. Penyajian data ini dilakukan dengan evaluasi kinerja keuangan berdasarkan laporan realisasi dan anggaran yang telah dianalisis.

d. Penarikan kesimpulan, melakukan simpulan dari hasil penelitian yang dilakukan mengenai Value for Money dalam pengukuran kinerja keuangan.

\section{PEMBAHASAN}

Pengukuran kinerja Pemerintah Daerah Kota Medandengan metode Value For Money yang diukur dengan menggunakan rasio ekonomis, rasio efisiensi dan rasio efektivitasatas pajak daerah, dimana penjelasannya adalah sebagai berikut:

\section{Rasio Ekonomis}

Ekonomi memiliki pengertian bahwa dalam memperoleh sumber daya sebaiknya dengan harga yang lebih rendah atau harga yang mendekati harga pasar. Suatu kinerja organisasi dikatakan ekonomis apabila realisasi anggaran lebih kecil daripada target anggaran dan dapat mencapai output yang maksimal. Perhitungan tersebut digunakan karena sulitnya mengkonversikan SDM dan sarana dan prasarana yang digunakan ke dalam satuan moneter dan menentukan berapa harga input yang sesungguhnya diperlukan.

Dengan semakin besar rasio ekonomis menunjukkan pemerintah mampu dalam memprediksi biaya atas pengeluaran, maka kinerja keuangan pemerintah daerah semakin baik. Dalam penelitian ini pengukuran ekonomi dilakukan dengan perhitungan sebagai berikut:

\section{Ekonomis $=$}

Realisasi Biaya Untuk Memperoleh Pendapatan $\overline{\text { Anggaran Biaya Untuk Memperoleh Pendapatan }}$ $\mathrm{x} 100 \%$

\section{Ketentuan:}

1) Jika > $100 \%$ maka Sangat Ekonomis

2) Jika $90 \%-100 \%$ maka Ekonomis

3) Jika $80 \%-90 \%$ maka Cukup Ekonomis

4) Jika 60\%-80\% maka Kurang Ekonomis

5) Jika $<60 \%$ maka Tidak Ekonomis 
Tabel 6

\section{Rasio Ekonomis Pemerintah Kota Medan}

\begin{tabular}{|l|l|l|l|}
\hline Tahun & $\begin{array}{c}\text { Realis } \\
\text { asi } \\
\text { Belan } \\
\text { ja } \\
\text { Daera } \\
\text { h }\end{array}$ & $\begin{array}{c}\text { Anggaran } \\
\text { Belanja } \\
\text { Daerah }\end{array}$ & \multicolumn{1}{|c|}{$\begin{array}{c}\text { Rasio } \\
\text { Ekonomi }\end{array}$} \\
\hline 2014 & 3.72 & 4.625 .1 & $80,50 \%$ \\
& 3.64 & 69.942. & \\
& 3.29 & 881 & \\
& 9.08 & & \\
& 5,60 & & \\
\hline 2015 & 4.37 & 5.467 .9 & $80 \%$ \\
& 4.96 & 52.757. & \\
& 8.27 & 114 & \\
& 4.13 & & \\
& 6,94 & & \\
\hline 2016 & 4.52 & 5.735 .9 & $79 \%$ \\
& 3.67 & 22.591. & \\
& 2.13 & 995 & \\
& 4.65 & & \\
& 5,15 & & \\
\hline 2017 & 4.39 & 5.546 .7 & $79 \%$ \\
& 4.04 & 33.964. & \\
& 5.82 & 019 & \\
& 4.26 & & \\
& 4,53 & & \\
\hline 2018 & 4.21 & 5.449 .5 & $77,31 \%$ \\
& 3.48 & 62.922. & \\
& 0.50 & 528 & \\
& 9.72 & & \\
& 6,24 & & \\
\hline
\end{tabular}

Sumber: Laporan Realisasi Anggaran yang telah diolah

Dilihat dari tabel 6, maka untuk Rasio ekonomis Pemerintah Kota Medan yang diukur dalam 5 tahun, dimana:

1) Untuk tahun 2014 rasio ekonomis sebesar $80,50 \%$, termasuk dalam kategori cukup ekonomis karena berada diantara $80 \%$ sampai dengan $90 \%$.

2) Untuk tahun 2015 rasio ekonomis mengalami penurunan menjadi $80 \%$, dan termasuk dalam kategori kurang ekonomis karena berada diantara $60 \%$ sampai dengan $80 \%$.

3) Untuk tahun 2016 rasio ekonomis sebesar $79 \%$ dan mengalami penurunan kembali, yang termasuk dalam kategori kurang ekonomis karena berada diantara $60 \%$ sampai dengan $80 \%$.

4) Untuk tahun 2017 rasio ekonomis tetap sebesar $79 \%$, yang mana masih termasuk dalam kategori kurang ekonomis karena berada diantara $60 \%$ sampai dengan $80 \%$.

5) Di tahun 2018 rasio ekonomis kembali mengalami penurunan menjadi $77,31 \%$, yang termasuk dalam kategori kurang ekonomis karena berada diantara $60 \%$ sampai dengan 80\%. Dapat dikatakan, Rasio ekonomis yang paling rendah berada pada tahun 2018. Dimana standar dari rasio ekonomis yang seharusnya dicapai kota Medan yaitu > 100\% masih belum bisa dicapai untuk tahun 2014-2018, dapat dikatakan bahwa Pemerintah Kota Medan belum dapat mengelola anggaran secara ekonomis.

Rasio ekonomis sering disebut penghematan yang mencakup pengelolaan secara cermat dan tidak ada pemborosan. Dengan semakin besar persentase ekonomis 


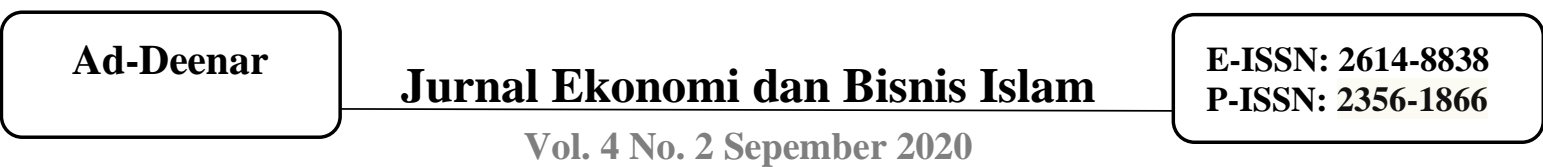

maka kinerja keuangan pemerintah daerah semakin baik. Grafik pengukuran kinerja value for money untuk rasio efektivitas dari tahun anggaran 2014-2018 adalah sebagai berikut:

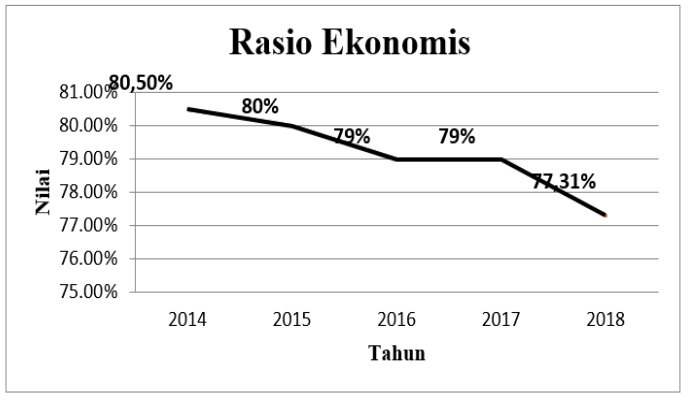

Gambar 2

Perkembangan Rasio Ekonomis

Pemerintah Daerah Kota Medan

Tahun Anggaran 2014 - 2018 (Sumber: data diolah)

Berdasarkan gambar 2 perkembangan rasio ekonomis menurun setiap tahunnya. Tahun anggaran 2014 sampai dengan 2015 mengalami penurunan sebesar $0,50 \%$ dan termasuk dalam kategori cukup ekonomis. Tahun 2015 sampai dengan 2016 mengalami penurunan sebesar $1 \%$ dan termasuk dalam kategori kurang ekonomis. Tahun anggaran 2017 grafik tidak mengalami kenaikan maupun penurunan dan masih berada dalam kategori kurang ekonomis. Tahun anggaran 2018 kembali mengalami penurunan yang signifikan sebesar 1,69\%. Ini menunjukkan bahwa pemerintah kota Medan belum disiplin dalam menggunakan anggaran pada saat memulai pelaksanaan program pemerintah dan pada akhir masa pelaksanaannya.
Program-program pemerintah banyak terjadi pemborosan pada penggunaan belanja operasi. Belanja operasi meliputi belanja pegawai, belanja barang jasa, belanja bunga, belanja subsidi, belanja hibah, belanja bantuan social, dan belanja bantuan keuangan. Tahun anggaran 2014 menjadi yang terbaik karena menghasilkan rasio ekonomis sebesar $80,50 \%$ dan dikatakan cukup ekonomis.

\section{Rasio Efisiensi}

Kinerja pemerintah daerah Kota Medan dikatakan efisien apabila rasio yang dihasilkan atau dicapai adalah $<1$ atau tidak lebih dari $100 \%$. Semakin kecil nilai rasio efisiensi maka semakin baik kinerja pemerintah daerah Kota Medan.

Berikut diuraikan perhitungan rasio efisiensi berdasarkan rumus yang digunakan yaitu sebagai berikut:

$\begin{aligned} & \text { Efisiensi } \\ & \text { Realisasi Biaya Untuk Memperoleh Pendapatan }\end{aligned}$
X $100 \%$

\section{Ketentuan:}

1) Jika > 100\% maka Tidak Efisien

2) Jika 90\%-100\% maka Kurang Efisien

3) Jika $80 \%-90 \%$ maka Cukup Efisien

4) Jika 60\%-80\% maka Efisien

5) Jika $<60 \%$ maka Sangat Efisien.

Tabel 7

Rasio Efisiensi Pemerintah Kota Medan

\begin{tabular}{|c|c|c|c|}
\hline Ta & Realisasi & Realisasi & Rasi \\
hu & Belanja & Pendapata & o \\
n & Daerah & n & $\begin{array}{c}\text { Efisi } \\
\text { ensi }\end{array}$ \\
& & & \\
\hline
\end{tabular}




\begin{tabular}{|l|l|l|l|}
\hline 201 & 3.723 .643 .2 & 4.042 .115 .8 & 92,1 \\
4 & $99.085,60$ & $28.231,62$ & $2 \%$ \\
\hline 201 & 4.374 .968 .2 & 4.259 .044 .4 & 102, \\
5 & $74.136,94$ & $90.715,42$ & $72 \%$ \\
\hline 201 & 4.523 .672 .1 & 4.308 .116 .9 & 105 \\
6 & $34.655,15$ & $16.024,91$ & $\%$ \\
\hline 201 & 4.394 .045 .8 & 4.409 .065 .4 & 99,6 \\
7 & $24.264,53$ & $82.201,50$ & $9 \%$ \\
\hline 201 & 4.213 .480 .5 & 4.253 .618 .7 & 99,0 \\
8 & $09.726,24$ & $58.533,00$ & $5 \%$ \\
\hline
\end{tabular}

Sumber: Laporan Realisasi Anggaran yang telah diolah

Dilihat dari tabel 7, maka untuk Rasio efisiensi Pemerintah Kota Medan yang diukur dalam 5 tahun, dimana:

1) Untuk tahun 2014 rasio efisiensi sebesar 92,12\%, yang termasuk dalam kategori kurang efisien karena untuk tahun 2014 berada diantara $90 \%$ sampai dengan $100 \%$.

2) Untuk tahun 2015 rasio efisiensi mengalami peningkatan menjadi $102,72 \%$, termasuk dalam kategori tidak efisien karena berada diatas $100 \%$.

3) Untuk tahun 2016 rasio efisiensi mengalami peningkatan menjadi $105 \%$, yang termasuk dalam kategori tidak efisien karena berada diatas $100 \%$.

4) Untuk tahun 2017 rasio efiensi mengalami penurunan menjadi $99,69 \%$, yang termasuk dalam kategori kurang efisien karena berada diantara $90 \%$ dan $100 \%$.

5) Ditahun 2018 rasio efisiensi mengalami penurunan menjadi
99,05\%, yang termasuk dalam kategori kurang efisien karena berada diantara $90 \%$ sampai $100 \%$. Dapat dikatakan, Rasio Efisiensi yang paling rendah berada pada tahun 2014, yaitu sebesar 92,12\% yang menunjukkan bahwa kinerja pemerintah Kota Medan dapat dikatakan masih belum efisien di tahun 2014-2018.

Grafik pengukuran kinerja Value for Money untuk rasio efisiensi dari tahun anggaran 2014 sampai dengan tahun 2018 sebagai berikut:

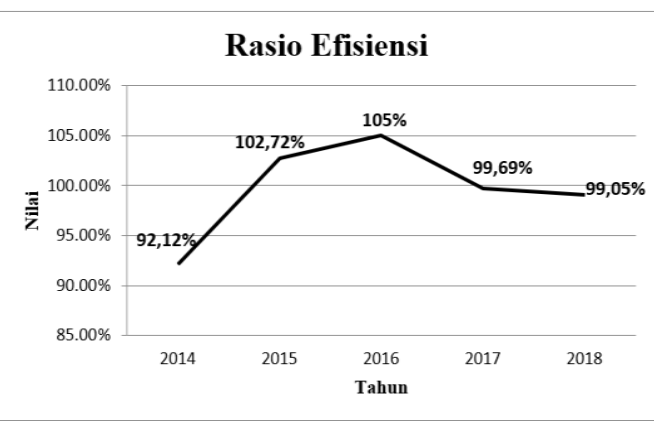

Gambar 3

Perkembangan Rasio Efisiensi Pemerintah Daerah Kota Medan Tahun Anggaran 2014 - 2018 (Sumber: Data diolah)

Berdasarkan gamabr 3 menunjukkan bahwa terjadi kenaikan dan penurunan pada rasio efisiensi. Rasio efisiensi untuk tahun anggaran 2014 sampai dengan 2015 mengalami kenaikan sebesar $10,6 \%$ yang menyebabkan rasio efisiensi berada dalam kategori tidak efisien. Tahun anggaran 2015 sampai dengan 2016 mengalami 
kenaikan sebesar 2,28\% dan kembali berada dalam kategori tidak efisien. Tahun anggaran 2016 dengan 2017 mengalami penurunan sebesar $5,31 \%$ dan termasuk dalam kategori kurang efisien. Tahun anggaran 2017 dengan 2018 mengalami penurunan sebesar $0,64 \%$ masih termasuk dalam kategori kurang efisien.

Melalui analisis rasio efisien dapat diketahui seberapa besar efisien dalam belanja daerah dalam meningkatkan pendapatan daerah Kota Medan. Dengan perhitungan rasio efisiensi ini dilakukan untuk mengetahui seberapa besar belanja daerah yang dikeluarkan oleh Pemerintah Kota Medan dalam meningkatkan pendapatan daerah. Dapat dikatakan untuk tahun 2014-2018 Pemerintah Kota Medan belum mampu menggunakan sumber daya yang diperlukan dengan mengefisiensikan pengeluaran untuk mencapai target yang dicapai. Apabila pemerintah daerah berhasil merealisasikan anggaran belanja sesuai dengan target yang ditetapkan, keberhasilan itu kurang memiliki arti apabila ternyata biaya yang dikeluarkan untuk merealisasikan anggaran belanja tersebut lebih besar daripada realisasi anggaran pendapatan yang diterima.

\section{Rasio Efektivitas}

Kinerja Pemerintah Daerah Kota Medan dikatakan efektif apabila rasio yang dihasilkan atau dicapai adalah lebih dari
$100 \%$. Semakin tinggi nilai rasio efektivitas maka semakin baik kinerja Pemerintah Daerah Kota Medan.

Berikut diuraikan perhitungan rasio efektivitas berdasarkan rumus yang digunakan yaitu sebagai berikut:

$$
\begin{aligned}
& \text { Efektivitas } \\
& \frac{\text { Realisasi Pendapatan }}{\text { Target Pendapatan }} \times 100 \%
\end{aligned}
$$

\section{Ketentuan:}

1) Jika $>100 \%$ maka Sangat Efektif

2) Jika $90 \%-100 \%$ maka Efektif

3) Jika 80\%-90\% maka Cukup Efektif

4) Jika 60\%-80\% maka Kurang Efektif

5) Jika $<60 \%$ maka Tidak Efektif

\section{Tabel 8}

Rasio Efektivitas Pemerintah Kota

\begin{tabular}{|c|c|c|c|}
\hline Tahun & $\begin{array}{c}\text { Realisasi } \\
\text { Pendapatan }\end{array}$ & $\begin{array}{c}\text { Anggaran } \\
\text { Pendapatan }\end{array}$ & $\begin{array}{l}\text { Rasio } \\
\text { Efektiv } \\
\text { itas }\end{array}$ \\
\hline 2014 & $\begin{array}{l}4.042 .115 . \\
828.231,6 \\
2\end{array}$ & $\begin{array}{l}4.560 .412 .52 \\
9.543,87\end{array}$ & $\begin{array}{l}88,6 \\
3 \%\end{array}$ \\
\hline 2015 & $\begin{array}{l}4.259 .044 . \\
490.715,4 \\
2\end{array}$ & $\begin{array}{l}5.046 .111 .83 \\
9.162,45\end{array}$ & $\begin{array}{l}84,4 \\
0 \%\end{array}$ \\
\hline 2016 & $\begin{array}{l}4.308 .116 . \\
916.024,9 \\
1\end{array}$ & $\begin{array}{l}5.490 .162 .68 \\
3.364,97\end{array}$ & $\begin{array}{l}78,4 \\
6 \%\end{array}$ \\
\hline 2017 & $\begin{array}{l}4.409 .065 . \\
482.200,5 \\
0\end{array}$ & $\begin{array}{l}5.523 .623 .11 \\
7.419,00\end{array}$ & $\begin{array}{l}79,8 \\
2 \%\end{array}$ \\
\hline 2018 & $\begin{array}{l}4.253 .618 . \\
758.533,0 \\
0\end{array}$ & $\begin{array}{l}5.239 .408 .01 \\
1.116,00\end{array}$ & $\begin{array}{l}81,1 \\
8 \%\end{array}$ \\
\hline
\end{tabular}
Medan

\section{Sumber: Laporan Realisasi Anggaran yang telah diolah}

Dilihat dari tabel 8, maka untuk Rasio Efektivitas Pemerintah Kota Medan yang diukur dalam 5 tahun, dimana:

1) untuk tahun 2014 rasio efektivitas sebesar 88,63\% yang termasuk dalam kategori cukup efektif karena 
untuk tahun 2014 berada diantara $80 \%$ sampai dengan $90 \%$.

2) Untuk tahun 2015 Rasio Efektivitas mengalami penurunan menjadi $84,40 \%$ dan termasuk dalam kategori cukup efektif karena berada diantara $80 \%$ sampai dengan $90 \%$.

3) Untuk tahun 2016 Rasio Efektivitas kembali mengalami penuruan menjadi $78,46 \%$ dan termasuk dalam kategori kurang efektif karena berada diantara $60 \%$ sampai dengan $80 \%$.

4) Untuk tahun 2017 Rasio Efektivitas mengalami kenaikan namun masih berada dalam kategori kurang efektif karena berada diantara $60 \%$ sampai dengan $80 \%$.

5) Kemudian untuk tahun 2018 Rasio Efektivitas mengalami kenaikan sebesar 81,18\% yang mana termasuk dalam kategori cukup efektif karena berada diantara $80 \%$ sampai dengan 90\%. Rasio Efektivitas yang tertinggi berada pada tahun 2014, yang termasuk dalam kategori cukup efektif yaitu $88,63 \%$.

Grafik pengukuran kinerja Value for Money untuk rasio efektivitas dari tahun anggaran 2014 sampai dengan tahun 2018 sebagai berikut:

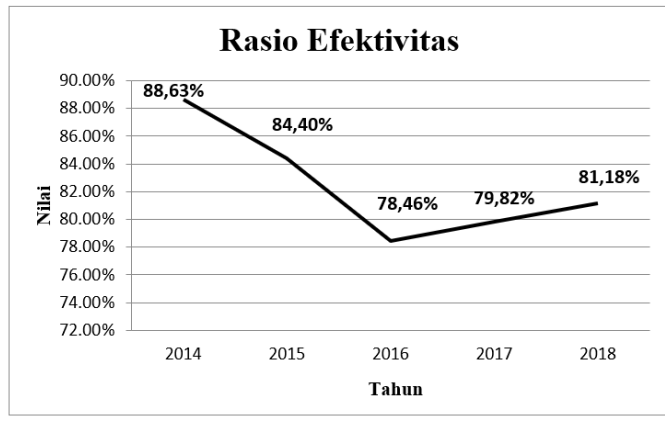

\section{Gambar 4}

Perkembangan Rasio Efektivitas Pemerintah Daerah Kota Medan Tahun Anggaran 2014 - 2018 (Sumber: Data diolah)

Berdasarkan gambar 4 menunjukkan bahwa terjadi kenaikan dan penurunan pada rasio efektivitas. Rasio efektivitas untuk tahun anggaran 2014 sampai dengan 2015 mengalami penurunan sebesar $4,23 \%$ yang menyebabkan rasio efektifitas berada dalam kategori cukup efektif. Tahun anggaran 2015 sampai dengan 2016 mengalami penurunan sebesar $5,94 \%$ dan kembali berada dalam kurang efektif. Tahun anggaran 2016 dengan 2017 mengalami kenaikan sebesar $1,36 \%$ dan termasuk dalam kategori kurang efektif. Tahun anggaran 2017 dengan 2018 mengalami kenaikan sebesar 1,36\% termasuk dalam kategori cukup efektif. Tahun anggaran 2014 menjadi yang terbaik karena menghasilkan rasio efektivitas sebesar 88,63\% dan dikatakan cukup efektif.

Pemerintah daerah dikatakan berhasil jika dapat merealisasikan anggaran pendapatan lebih besar dari target pendapatan yang ditetapkan, dan biaya 


\section{Ad-Deenar}

yang dikeluarkan untuk merealisasikan anggaran belanja lebih kecil dari target belanja yang diterima. Dapat dikatakan bahwa untuk tahun 2014-2018 perhitungan kinerja menggunakan rasio efektivitas dikategorikan cukup efektif. Hal ini menunjukkan bahwa Pemerintah Kota Medan sudah berhasil dalam menjalankan program kerjanya, karena realisasi anggaran sudah mendekati target anggaran yang telah ditetapkan. Tetapi masih banyak output yang dihasilkan terhadap pencapaian belum sesuai tujuan atau sasaran.

Berikut ini adalah data perhitungan mengenai tingkat ekonomis, efisiensi dan efektivitas Anggaran Pendapatan Kota Medan:

\section{Tabel 9}

Pengukuran Tingkat Ekonomis, Efisiensi dan Efektivitas Anggaran Pendapatan Kota Medan Tahun 2014-2018

\begin{tabular}{|c|c|c|c|c|c|}
\hline Tahun & $\begin{array}{l}2 \\
0 \\
1 \\
4\end{array}$ & 2015 & $\begin{array}{c}201 \\
6\end{array}$ & $\begin{array}{c}201 \\
7\end{array}$ & $\begin{array}{c}201 \\
8\end{array}$ \\
\hline $\begin{array}{l}\text { Rasio } \\
\text { Ekono } \\
\text { mis }\end{array}$ & $\begin{array}{l}8 \\
0 \\
\text { 5 } \\
\mathbf{0} \\
\%\end{array}$ & $80 \%$ & $\begin{array}{l}79 \\
\%\end{array}$ & $\begin{array}{l}79 \\
\%\end{array}$ & $\begin{array}{l}\mathbf{7 7}, \\
\mathbf{3 1} \\
\%\end{array}$ \\
\hline $\begin{array}{l}\text { Kriteri } \\
\text { a }\end{array}$ & $\begin{array}{l}\mathrm{C} \\
\mathrm{u} \\
\mathrm{k} \\
\mathrm{u} \\
\mathrm{p} \\
\mathrm{E} \\
\mathrm{k} \\
\mathrm{o} \\
\mathrm{n} \\
\mathrm{o} \\
\mathrm{m} \\
\text { is }\end{array}$ & $\begin{array}{l}\text { Cuku } \\
\text { p } \\
\text { Ekon } \\
\text { omis }\end{array}$ & $\begin{array}{c}\mathrm{Ku} \\
\text { ran } \\
\mathrm{g} \\
\mathrm{Ek} \\
\text { ono } \\
\text { mis }\end{array}$ & $\begin{array}{c}\text { Kur } \\
\text { ang } \\
\text { Eko } \\
\text { nom } \\
\text { is }\end{array}$ & $\begin{array}{c}\text { Kur } \\
\text { ang } \\
\text { Eko } \\
\text { no } \\
\text { mis }\end{array}$ \\
\hline $\begin{array}{l}\text { Rasio } \\
\text { Efisien } \\
\text { si }\end{array}$ & $\begin{array}{l}9 \\
2 \\
,\end{array}$ & $\begin{array}{l}102 \\
72 \%\end{array}$ & $\begin{array}{c}105 \\
\%\end{array}$ & $\begin{array}{l}99,6 \\
9 \%\end{array}$ & $\begin{array}{c}99, \\
05 \\
\%\end{array}$ \\
\hline
\end{tabular}

\begin{tabular}{|c|c|c|c|c|c|}
\hline & $\begin{array}{l}1 \\
2 \\
\%\end{array}$ & & & & \\
\hline $\begin{array}{l}\text { Kriteri } \\
\text { a }\end{array}$ & $\begin{array}{l}\mathrm{K} \\
\mathrm{u} \\
\mathrm{r} \\
\mathrm{a} \\
\mathrm{n} \\
\mathrm{g} \\
\mathrm{E} \\
\mathrm{fi} \\
\mathrm{si} \\
\mathrm{e} \\
\mathrm{n}\end{array}$ & $\begin{array}{c}\text { Tida } \\
\mathrm{k} \\
\text { Efisi } \\
\text { en }\end{array}$ & $\begin{array}{c}\text { Tid } \\
\text { ak } \\
\text { Efi } \\
\text { sie } \\
\text { n }\end{array}$ & $\begin{array}{c}\text { Kur } \\
\text { ang } \\
\text { Efisi } \\
\text { en }\end{array}$ & $\begin{array}{c}\text { Kur } \\
\text { ang } \\
\text { Efis } \\
\text { ien }\end{array}$ \\
\hline $\begin{array}{l}\text { Rasio } \\
\text { Efektivi } \\
\text { tas }\end{array}$ & $\begin{array}{l}8 \\
8 \\
6 \\
6 \\
3 \\
\%\end{array}$ & $\begin{array}{l}84,4 \\
0 \%\end{array}$ & $\begin{array}{l}78, \\
46 \\
\%\end{array}$ & $\begin{array}{c}79,8 \\
2 \%\end{array}$ & $\begin{array}{c}81, \\
18 \\
\%\end{array}$ \\
\hline $\begin{array}{l}\text { Kriteri } \\
\text { a }\end{array}$ & $\begin{array}{l}\mathrm{C} \\
\mathrm{u} \\
\mathrm{k} \\
\mathrm{u} \\
\mathrm{p} \\
\mathrm{E} \\
\mathrm{f} \\
\mathrm{e} \\
\mathrm{k} \\
\mathrm{ti} \\
\mathrm{f}\end{array}$ & $\begin{array}{c}\text { Cuku } \\
p \\
\text { Efekt } \\
\text { if }\end{array}$ & $\begin{array}{c}\mathrm{Ku} \\
\text { ran } \\
\mathrm{g} \\
\text { Efe } \\
\text { ktif }\end{array}$ & $\begin{array}{c}\text { Kur } \\
\text { ang } \\
\text { Efek } \\
\text { tif }\end{array}$ & $\begin{array}{l}\mathrm{Cu} \\
\text { kup } \\
\text { Efe } \\
\text { ktif }\end{array}$ \\
\hline
\end{tabular}

\section{Rasio Ekonomi}

Rasio ekonomis Pemerintah Kota Medan yang diukur selama 5 tahun (20142018), dimana untuk tahun 2014 diperoleh rasio ekonomis sebesar $80,50 \%$ berada dalam kategori cukup ekonomis, untuk tahun 2015 diperoleh rasio ekonomis sebesar $80 \%$ dan berada dalam kategori cukup ekonomis, untuk tahun 2016 diperoleh rasio ekonomis sebesar $79 \%$ dan berada dalam kategori kurang ekonomis, untuk tahun 2017 diperoleh rasio ekonomis sebesar $79 \%$ dan berada dalam kategori kurang ekonomis, kemudian untuk tahun 2018 diperoleh rasio ekonomis sebesar 
$77,31 \%$ dan berada dalam kategori kurang ekonomis. Rasio Ekonomis kinerja keuangan Pemerintah Kota Medan tahun 2014-2018 untuk keseluruhan diperoleh rata-rata sebesar $79 \%$ yang mana termasuk dalam kategori kurang ekonomis. Ini menunjukkan bahwa pemerintah Kota Medan belum dapat mengelola anggaran dengan cara yang ekonomis. Pengukuran ekonomi bertujuan untuk mengetahui kinerja Pemerintah Kota Medan periode tahun 2014-2018 dalam memperoleh dan mengelola sumber daya (input) yang dibutuhkan agar dapat menghindari pengeluaran yang boros dan tidak produktif. Keekonomian suatu kegiatan tidak hanya dilihat dari besarnya penghematan yang dilakukan oleh Pemerintah Kota Medan, tetapi juga harus mempertimbangkan keluaran (output) yang dihasilkan. Penghematan menjadi berkurang maknanya jika keluaran (output) yang dihasilkan tidak sesuai target atau tidak dapat tercapai secara maksimal. Ekonomis terkait dengan sejauh mana dapat meminimalisir input primer yang berupa anggaran atau kas menjadi input sekunder berupa tenaga kerja, bahan, infrastruktur dan barang modal yang dikonsumsi untuk pelaksanaan kegiatan operasi organisasi, dengan menggunakan anggaran dengan hemat (tidak boros) dan mampu mengelola keuangan dengan baik.

\section{Rasio Efisiensi}

Rasio efisiensi Pemerintah Kota Medan yang diukur selama 5 tahun (20142018), dimana untuk tahun 2014 diperoleh rasio efisiensi sebesar $92,12 \%$ berada dalam kategori kurang efisien, untuk tahun 2015 diperoleh rasio efisiensi sebesar 102,72\% dan berada dalam kategori tidak efisien, untuk tahun 2016 diperoleh rasio efisiensi sebesar $105 \%$ dan berada dalam kategori tidak efisien, untuk tahun 2017 diperoleh rasio efisiensi sebesar 99,69\% dan berada dalam kategori kurang efisien, kemudian untuk tahun 2018 diperoleh rasio efisiensi sebesar 99,05\% dan berada dalam kategori kurang efisien. Rasio Efisiensi kinerja keuangan Pemerintah Kota Medan tahun 2014-2018 secara keseluruhan diperoleh rata-rata sebesar $99,71 \%$ yang mana termasuk dalam kategori kurang efisien. Penyebab terjadinya ketidakefisienan anggaran tersebut dikarenakan terjadinya pemborosan-pemborosan pada sektor tertentu, seperti sudah tersedianya fasilitas yang sudah memadai tetapi masih ada anggaran untuk renovasi dan pengembangan, ini dapat dilihat dari besarnya anggaran belanja yang setiap tahun terus mengalami kenaikan, kemudian penyebab ketidakefisienan anggaran yaitu besarnya pengeluaran belanja yang didominasi belanja pegawai, seperti perjalanan dinas/kegiatan rapat diluar 
kantor atau pengadaan kendaraan dinas baru di Instansi pemerintahan. Besarnya realisasi anggaran belanja dari realisasi pendapatan yang diterima mengindikasikan bahwa tingkat efisiensi pengelolaan keuangan masih sangat kurang dan terkesan adanya pemborosan dengan tidak mengindahkan azas penghematan dan efisiensi anggaran belanja daerah. Keberhasilan pemerintah dalam merealisasikan target anggaran belanja sesuai dengan target yang telah ditetapkan, kurang memiliki arti apabila biaya yang dikeluarkan untuk merealisasikan target anggaran belanja lebih besar dari realisasi anggaran pendapatan yang diterima.

\section{Rasio Efektivitas}

Rasio efektivitas Pemerintah Kota Medan yang diukur selama 5 tahun (20142018), dimana untuk tahun 2014 diperoleh rasio efektivitas sebesar $88,63 \%$ berada dalam kategori cukup efektif, untuk tahun 2015 diperoleh rasio efektivitas sebesar $84,40 \%$ dan berada dalam kategori cukup efektif, untuk tahun 2016 diperoleh rasio efektivitas sebesar $78,46 \%$ dan berada dalam kategori kurang efektif, untuk tahun 2017 diperoleh rasio efektivitas sebesar $70,82 \%$ dan berada dalam kategori kurang efektif, kemudian untuk tahun 2018 diperoleh rasio efektivitas sebesar $81,18 \%$ dan berada dalam kategori cukup efektif. Rasio Efektivitas kinerja keuangan
Pemerintah Kota Medan dari tahun 20142018 diperoleh rata-rata sebesar 82,49\% yang mana termasuk dalam kategori cukup efektif. Pengukuran Efektivitas merupakan rasio yang menggambarkan akibat dari dampak (outcome) dari output program dalam mencapai tujuan program. Efektivitas adalah ukuran berhasil tidaknya suatu organisasi mencapai tujuannya. Semakin besar output yang dihasilkan terhadap pencapaian tujuan atau sasaran yang ditentukan, maka semakin efektif proses kerja suatu unit organisasi. Hal ini menunjukkan bahwa Pemerintah Kota Medan sudah berhasil dalam menjalankan program kerjanya, karena realisasi anggaran sudah mendekati target anggaran yang telah ditetapkan. Tetapi masih banyak output yang dihasilkan terhadap pencapaian belum sesuai tujuan atau sasaran. Contohnya adalah proyek pembangunan tanpa manfaat di Kota Medan dapat dijumpai pada proyek Sky Bridge yang sampai saat ini proyek dengan anggaran sebesar Rp. 35 Miliar tersebut tidak member manfaat apapun bagi warga kota karena tak kunjung difungsikan dan terbengkalai. Kemudian, proyek pembangunan kanal banjir di Titi Kuning. Proyek yang diharapkan mampu mengatasi masalah banjir di Kota Medan ini belum memberi manfaat berarti dalam pengendalian banjir kota. Di kawasan jalan 
Brigjen Katamso, STM, Marendal dan Johor, apabila memasuki musim penghujan menjadi langganan banjir dengan tingkat genangan air yang cukup tinggi. Pengukuran efektivitas Kota Medan belum memenuhi kriteria sangat efektif karena realisasi anggaran belum mendekati target anggaran yang telah ditetapkan. Anggaran yang cukup jauh perbedaannya dengan target yang diharapkan disebabkan oleh adanya kegiatan yang dianggarkan, tetapi tidak dilaksanakan.

Adapun cara yang dapat dilakukan untuk meningkatkan rasio value for money agar kedepannya dapat memenuhi kriteria adalah:

a. Rasio Ekonomi yang tidak memenuhi kriteria, agar memaksimalkan penggunaan biaya untuk belanja modal, karena dana yang dikeluarkan untuk belanja modal masih terlalu jauh dari anggaran yang diberikan oleh pemerintah pusat dan dianggap belum maksimal dalam pelayanan masyarakat. Ekonomi sering disebut kehematan yang mencakup juga pengelolaan secara berhati-hati atau cermat dan tidak ada pemborosan.

b. Rasio Efisiensi yang tidak memenuhi kriteria efisien, agar menekankan biaya untuk belanja operasi khususnya belanja pegawai dan meningkatkan belanja modal agar kualitas masyarakat seimbang dengan belanja yang dikeluarkan pemerintah daerah. Proses kegiatan operasional dapat dikatakan efisien apabila suatu produk atau hasil kerja tertentu dapat dicapai dengan penggunaan sumber daya dan dana yang serendah-rendahnya (spending well).

c. Rasio Efektivitas yang tidak memenuhi kriteria efektif, berusaha semaksimal mungkin didalam meningkatkan pendapatan daerah khususnya pendapatan asli daerah dengan baik melalui pajak maupun retribusi, sehingga hasil yang dicapai lebih kecil dari target yang telah ditetapkan. Efektivitas merupakan ukuran berhasil tidaknya suatu organisasi mencapai tujuannya. Apabila suatu organisasi berhasil mencapai tujuan, maka organisasi tersebut dikatakan telah berjalan efektif.

\section{E. KESIMPULAN}

Hasil penelitian menunjukkan bahwa kinerja keuangan Pemerintah Kota Medan berdasarkan rasio Value for Money tergolong belum baik, karena realisasi program yang diukur dari tingkat rasio 


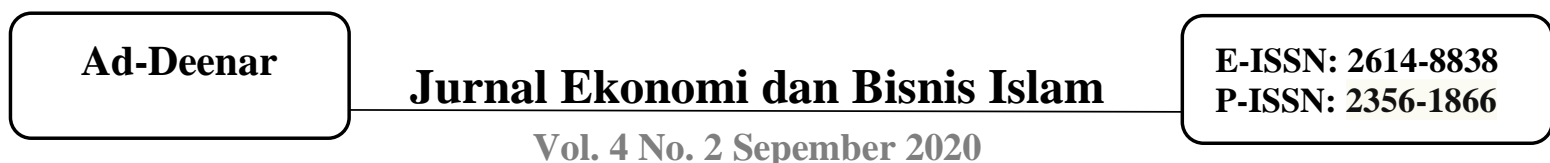

Vol. 4 No. 2 Sepember 2020

Value for Money selama tahun 2014-2018 mengalami penurunan setiap tahunnya. Adapun cara yang dilakukan untuk meningkatkan rasio value for money pada Pemerintah Kota Medan adalah Pemerintah Kota Medan harus optimal dalam mendapatkan pendapatan daerah, khususnya pendapatan asli daerah (PAD) dalam meningkatkan hasil kekayaan daerah agar mengurangi sumbangan dari pemerintah pusat dan penggunaan anggaran belanja daerah dilakukan tepat sasaran untuk memaksimalkan program kerja Pemerintah Kota Medan, serta menekankan biaya untuk belanja operasi dan meningkatkan belanja modal agar kualitas pelayanan kepada masyarakat seimbang dengan belanja yang dikeluarkan pemerintah daerah.

\section{DAFTAR PUSTAKA}

Badan Pengelola Keuangan dan Aset Daerah Kota Medan. (2014). Laporan Realisasi Anggaran. Tahun 2014-2016. bpkad.pemkomedan.go.id

Bastian, Indra, dan Gatot Soepriyanto. (2003). Sistem Akuntansi Sekor Publik, Konsep Untuk Pemerintah Daerah. Jakarta: Salemba Empat.

Depdagri. Kepmendagri No.690.900.327. 1996, Tentang Pedoman Penilaian dan Kinerja Keuangan, 1997.

Direktorat Jenderal Perimbangan Keuangan (DJPK), Kementrian Keuangan Republik Indonesia. Anggaran Pendapatan dan Belanja Daerah. Tahun 2017 dan 2018. www.djpk.go.id
Halim, Abdul. (2002). Akuntansi dan Pengendalian Keuangan Daerah Yogyakarta: Seri Bunga Rampai UUP AMP YMPN.

Mahsun, Muhammad. (2006) Pengukuran Kinerja Sektor Publik. Yogyakarta: BPFE.

Mardiasmo. (2002). Akuntansi Sektor Publik. Yogyakarta: Andi.

Peraturan Pemerintah dalam Negeri No. 13 Tahun 2006, Tentang Pedoman Pengelolaan Keuangan Daerah.

Peraturan Pemerintah Republik Indonesia Nomor 105 Tahun 2000 tentang Pengelolaan dan Pertanggungjawaban Keuangan Daerah

TJ, Putra. (2019) .Sky Bridge: Proyek Rp35 Miliar yang Terbengkalai 5 Tahun. https://www.gatra.com. Diunduh pada tanggal 2 Desember.

Umar, Husein. (2004). Metodelogi Penelitian untuk Skripsi dan Tesis Bisnis. Jakarta: PT RajaGrafindo. 
